\title{
The Effect of Sour Gases and Some Anions on the Corrosion Behavior of Carbon Steel
}

\author{
S.A. Salih, A.A. Mazhar, M.H. Mahanny ${ }^{* *}$ \\ Chemistry Department, Faculty of Sciences, Cairo University, Giza, Egypt
}

Received 15 January 2003; accepted in revised form 28 July 2004

\begin{abstract}
The effect of the presence of $\mathrm{CO}_{2}$ and $\mathrm{H}_{2} \mathrm{~S}$ in the well water used in the petroleum plant on corrosion of carbon steel has been tested using impedance measurements. Carbon dioxide leads to decrease in the resistivity of the film developed on the metallic surface, while the effect of hydrogen sulfide is less pronounced. Scanning electron micrographs have shown that corrosion products cover only small part of metallic surface in water containing $\mathrm{CO}_{2}$. Studies under polarization conditions will allow concluding that the dissolved gases in the well water reduce the ability of the film to protect the metal against corrosion. The influence of the oxoanions and halide ions on the corrosion rate of steel has also been analyzed.
\end{abstract}

Keywords: corrosion, sour gases, carbon steel, petroleum plant.

\section{Introduction}

Pipelines used for the transport of oil or gas from wells to production facilities are requested to have highly resistant properties to environments containing $\mathrm{H}_{2} \mathrm{~S}$. Further, the petroleum industry faces grave industrial problems by $\mathrm{CO}_{2}$ containing aqueous solutions, which cause the corrosion of carbon steels. Although the solubility of $\mathrm{CO}_{2}$ lowers the $\mathrm{pH}$ of the solution, it has been shown that acidification is not the only precursor of the corrosion of carbon steels [1]. The identity of the solid corrosion product affects significantly the rate and mechanism of corrosion of carbon steel in aqueous $\mathrm{CO}_{2}$ solutions [2-4]. Ferrous

\footnotetext{
* To whom correspondence should be addressed by mail: Att. Prof. Dr. Amina Mazhar.

** To whom correspondence should be addressed by E-mail: chemomemo@yahoo.com.
} 
carbonate films reduce significantly the rate of uniform corrosion and are therefore a prominent factor determining the behavior of carbon steels used in $\mathrm{CO}_{2}$ containing environment.

The presence of foreign ions in the well water is expected to produce an accelerating or suppressing effect on the corrosion of carbon steels. This work has been devoted to study the influence of $\mathrm{CO}_{2}, \mathrm{H}_{2} \mathrm{~S}$ and halide ions present in the well water on the corrosion of carbon steels.

\section{Experimental details}

The impedance measurements were carried out using a IM6 Zahner electrik, Messtecnik equipment, in the $10^{5}$ to $10^{-1} \mathrm{~Hz}$ frequency range with excitation amplitude of $10 \mathrm{mV}$ peak-to-peak as in a previous study [5].

The carbon steel alloy has the following composition: $1.13 \% \mathrm{C}, 1.09 \% \mathrm{Mn}$, $2.35 \% \mathrm{Si}, 0.42 \% \mathrm{Cu}$ and the balance is Fe. The electrode of $0.44 \mathrm{~cm}^{2}$ area was connected to a small copper wire and fixed in a glass tube with an epoxy adhesive resin (Araldite, Ciba-Production, Switzerland).

To achieve high reproducibility, the electrode was always pre-treated with the same procedure. The electrode was mechanically polished with successive abrasive papers (800-2000 grade). The final polish was made by rubbing with a fine tissue paper so that the surface was mirror bright. The electrode was then rinsed several times with bi-distilled water and immersed directly in the test solution.

Mogra water ( $\mathrm{pH}$ 6.7-6.8 and composition listed in Table 1) used in the work was collected from 1600 feet depth from the western desert near a petroleum plant.

All chemicals used were AnalR grade reagents. Measurements were carried out at constant temperature $(25 \pm 0.5){ }^{\circ} \mathrm{C}$.

\section{Results and discussion}

The Bode plot after 2 hours immersion of the specimen in mogra water is shown in Fig. 1. The Nyquist plots for the same water saturated with either $\mathrm{H}_{2} \mathrm{~S}$ or $\mathrm{CO}_{2}$ are shown in Fig. 2a. A well-defined high frequency capacitive semicircle is 
observed in the case of $\mathrm{CO}_{2}$ saturated water. The center of the semicircle is, however, well depressed below the real part of the impedance. This depression is often correlated with the microscopic roughness of the metal/solution interface and is often referred to as surface inhomogeneity [6].

Table 1. Composition of mogra water.

\begin{tabular}{cc}
\hline Component & Concentration range $(\mathrm{ppm})$ \\
\hline Chlorides & $16.000-18.000$ \\
Sulfates & $2.400-2.600$ \\
Nitrites & $0.5-0.6$ \\
Calcium & $1.078-1.098$ \\
Magnesium & $1.262-1.318$ \\
Sodium & $8.280-8.349$ \\
Bicarbonates & $112-128$ \\
Iron (II) & $6.0-7.0$ \\
\hline
\end{tabular}

The semicircle in the case of mogra water alone or saturated with $\mathrm{H}_{2} \mathrm{~S}$ is not well defined, and since this semicircle is correlated with the dielectric properties and thickness of the barrier film, it is reasonable to conclude that in these two cases more resistive films are formed on the carbon steel surface.

The Bode plot in Fig. 2b shows that Rp, the polarization resistance, in the case of $\mathrm{CO}_{2}$ saturated water, is apparently lower than that obtained in the case of mogra water alone. $\mathrm{Rp}$ is approximately determined by both the electrolytic conductance of the oxide film and polarization resistance of the dissolution and repassivation process. Rp can be readily estimated as the difference between the low frequency limit, which represents the sum of $\left(R_{\Omega}+R p\right)$ and the high frequency limit, which corresponds to the electrolytic resistance $\mathrm{R}_{\Omega}$. 


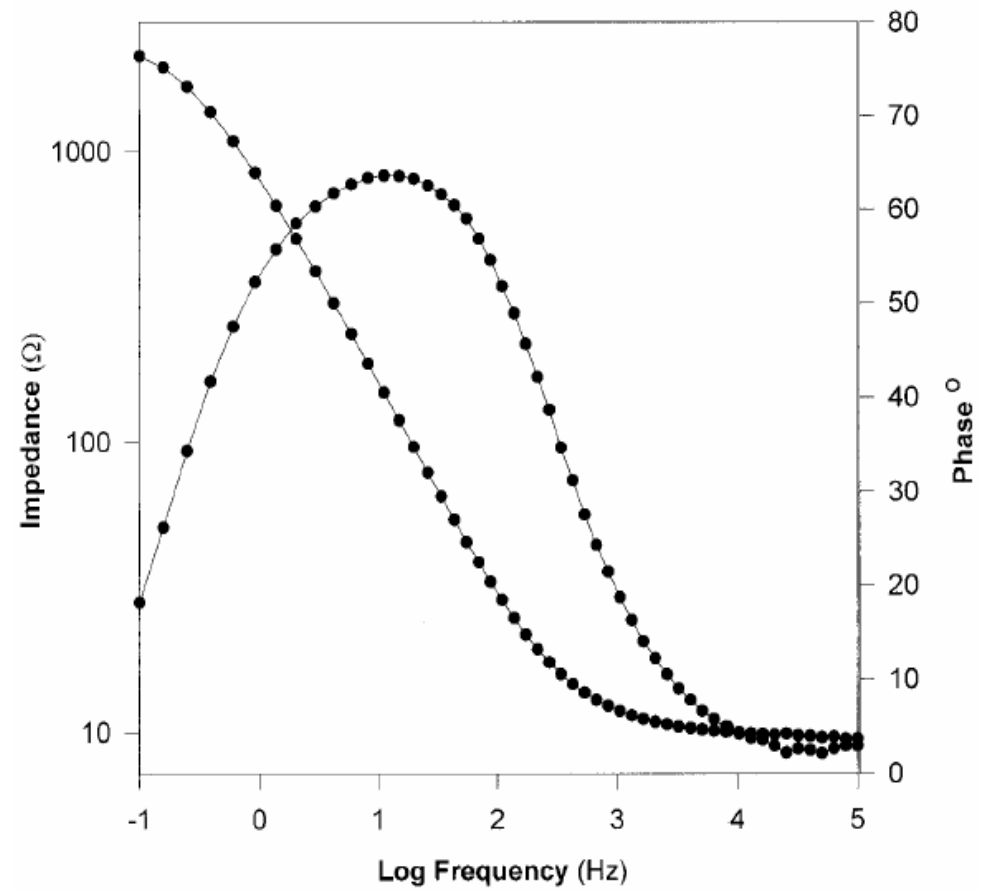

Figure 1. Bode-plot of mogra water at $25^{\circ} \mathrm{C}$ after $2 \mathrm{~h}$ immersion.

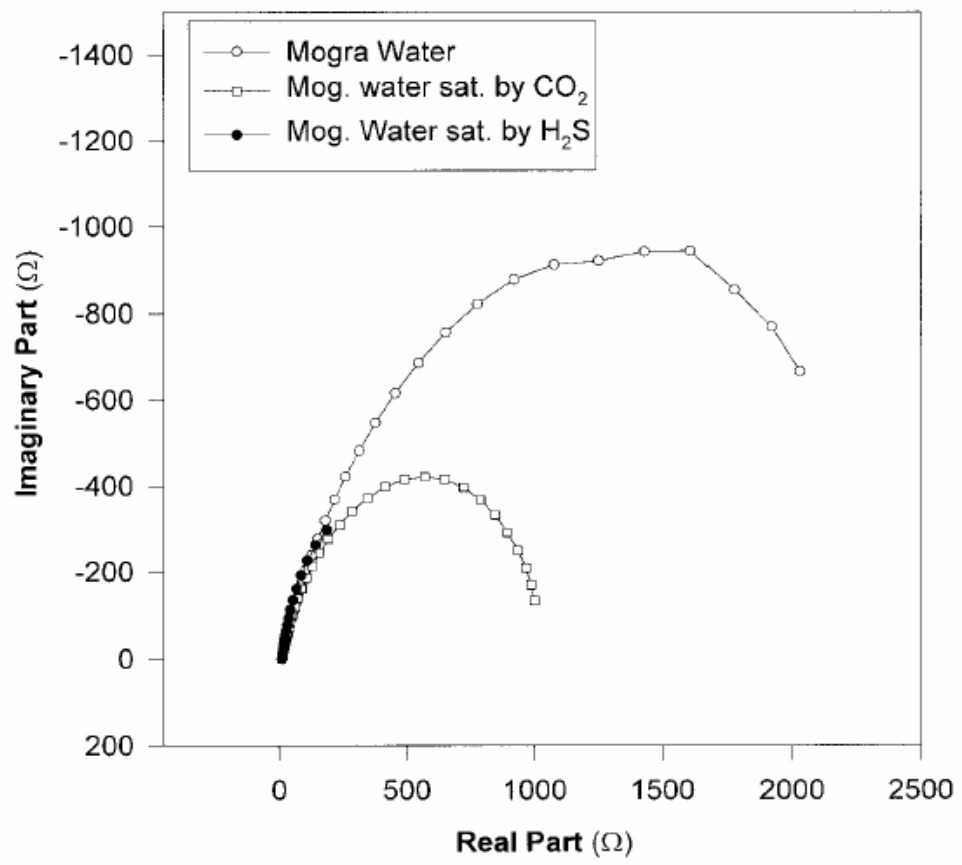

Figure 2a. Nyquist-plot for mogra water saturated by sour gases $\left(\mathrm{CO}_{2}\right.$ and $\left.\mathrm{H}_{2} \mathrm{~S}\right)$ at $25^{\circ} \mathrm{C}$ after $2 \mathrm{~h}$. 


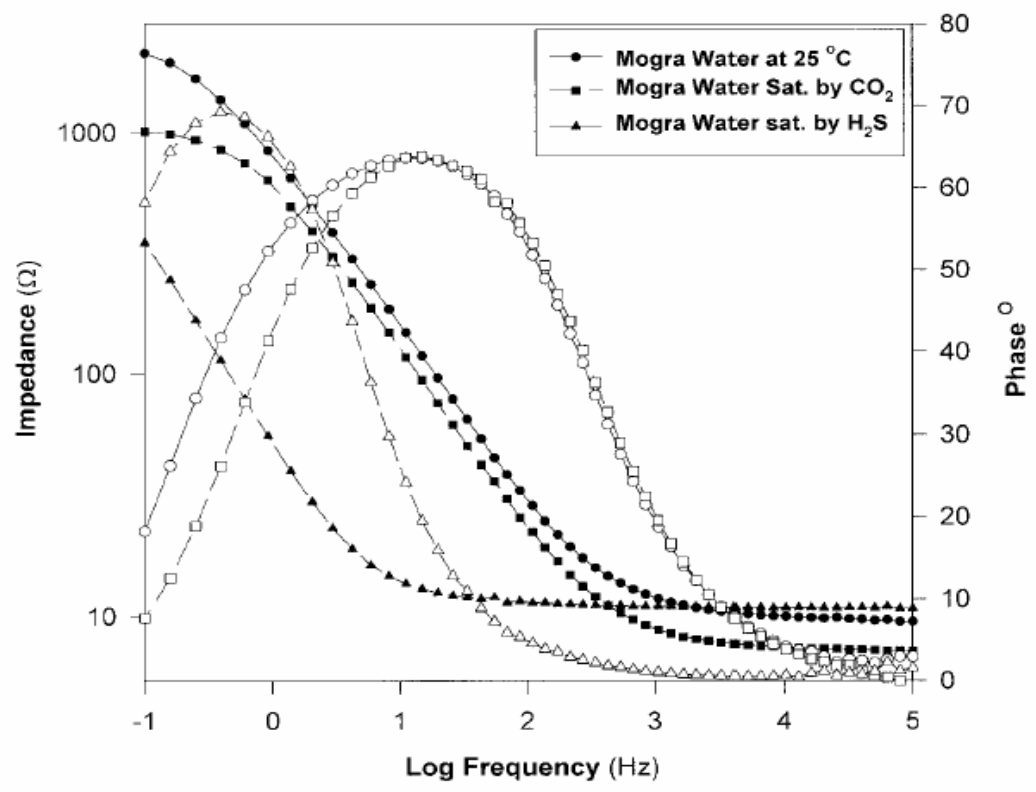

Figure 2b. Bode-plot for mogra water saturated by sour gases $\left(\mathrm{CO}_{2}\right.$ and $\left.\mathrm{H}_{2} \mathrm{~S}\right)$ at $25^{\circ} \mathrm{C}$ after $2 \mathrm{~h}$.

The phase angle between the current and potential $(\theta)$ is a sensitive index of film damage [7]. Values of $\theta$ for mogra water, $\mathrm{H}_{2} \mathrm{~S}$ and $\mathrm{CO}_{2}$ saturated water, were found to be 63.6, 69.2 and 63.8, respectively. The dielectric properties of the film formed in the case of $\mathrm{CO}_{2}$-saturated water is of a less resistive nature, as indicated also at intermediate frequencies by the more or less capacitive behavior of the system. A pure capacitive behavior should produce a slope of -1 in the $\log \mathrm{Z}-\log \mathrm{F}$ relation at intermediate frequencies. It has been proposed [8] that the role of $\mathrm{CO}_{2}$ is to accelerate the rate of the anodic reaction through the formation of carbonic acid, which reacts with iron to form iron carbonate via iron bicarbonate. The decrease in $\theta_{\max }$ in the mogra water where $\mathrm{CO}_{2}$ is absent can be reasonably assumed not to be due to film damage but by something else [9], which may be due to the corrosion products produced in this case. The shift of $\theta_{\max }$ to lower frequencies in the case of $\mathrm{H}_{2} \mathrm{~S}$ saturated water may be due to increase in the surface area exposed to the electrolyte. Trials to identify the equivalent circuit are shown in Fig. 3. It is clear that a simple Randle's circuit adequately represents the equivalent circuit in the case of $\mathrm{H}_{2} \mathrm{~S}$ saturated water. 


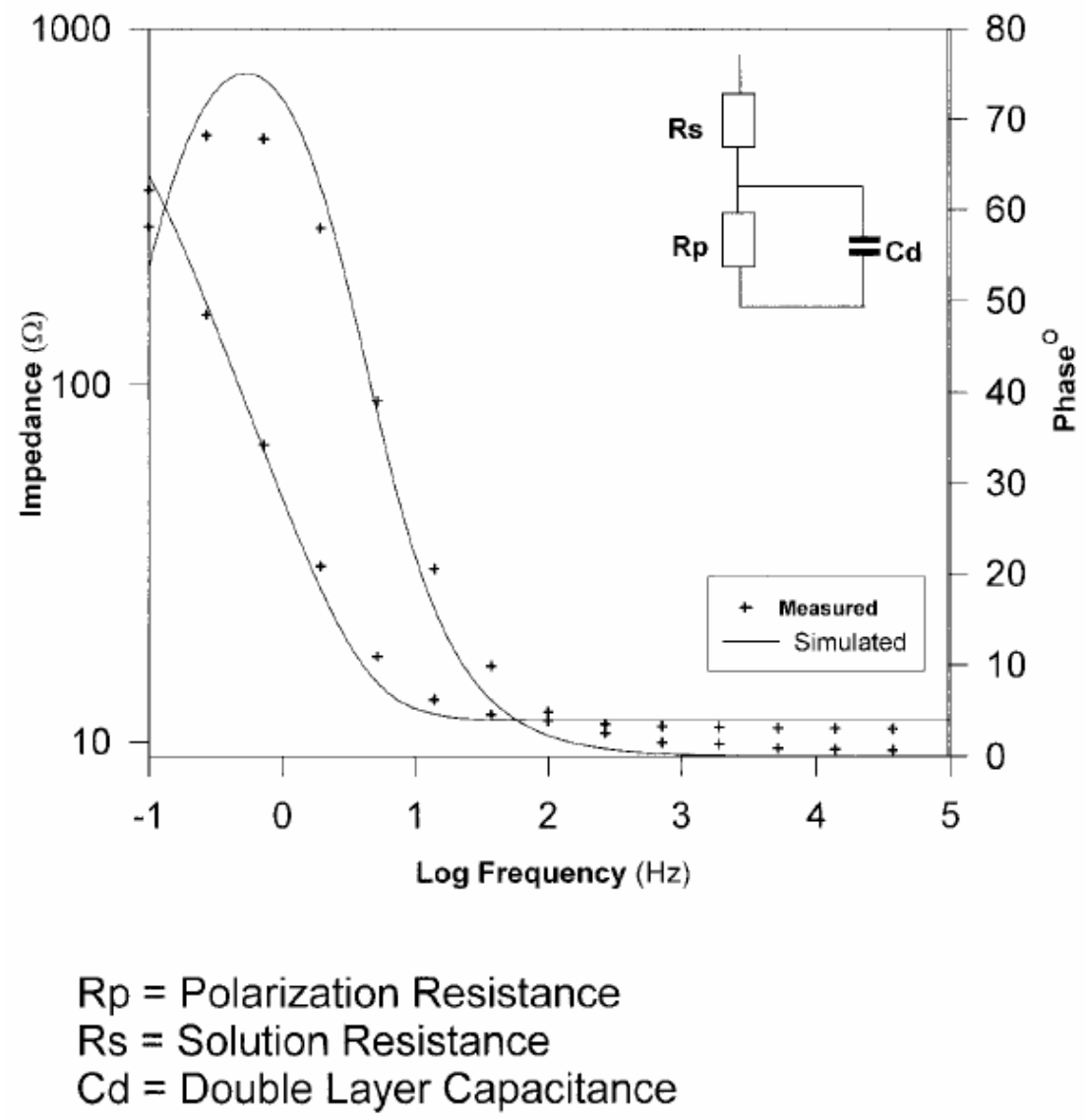

Figure 3a. Bode-plot of equivalent circuit for $\mathrm{H}_{2} \mathrm{~S}$ saturated mogra water at $25{ }^{\circ} \mathrm{C}$ after $2 \mathrm{~h}$.

Scanning electron micrographs of the specimen immersed for 2 hours in mogra water only or mogra water saturated with $\mathrm{CO}_{2}$ or $\mathrm{H}_{2} \mathrm{~S}$ are shown in Fig. 4a.

General corrosion is observed with formation of pits in the case of mogra water alone. Corrosion products appear to cover a large area of the surface. In the other two cases the surface is partly covered with the corrosion products, which allows more active behavior in these media. Fig. $4 \mathrm{~b}$ shows a higher magnification of the surface in the same media. In the case of mogra water alone, the surface is covered by bulky corrosion products which protect the surface, but deep pits are also observed. In the presence of $\mathrm{H}_{2} \mathrm{~S}$, fine needle shaped deposits appear on parts of the surface in addition to more bulky products and few pits can be detected. 

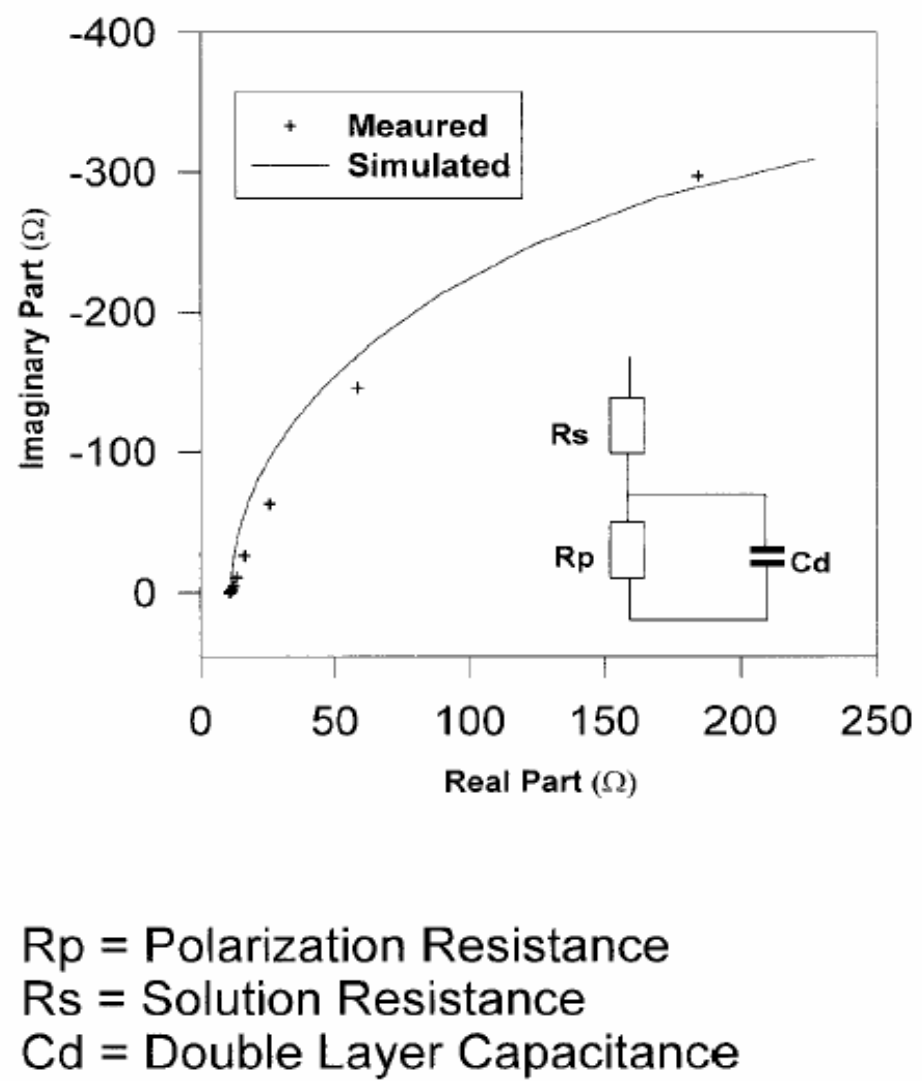

Figure 3b. Nyquist-plot of equivalent circuit for $\mathrm{H}_{2} \mathrm{~S}$ saturated mogra water at $25{ }^{\circ} \mathrm{C}$ after $2 \mathrm{~h}$.

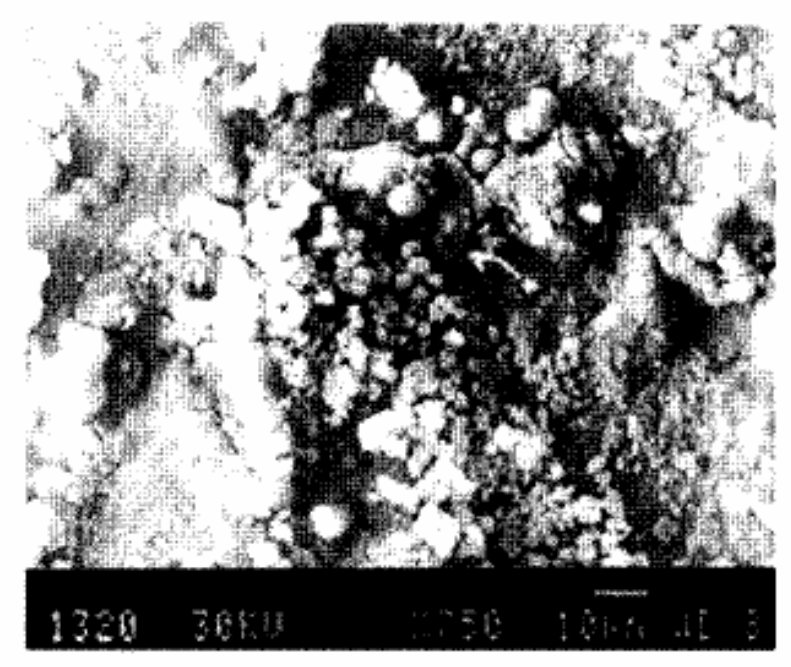

Figure 4a-I. SEM micrograph X750 showing corrosion products precipitated in pits in case of specimen immersed in mogra water at $25^{\circ} \mathrm{C}$ for $2 \mathrm{~h}$. 


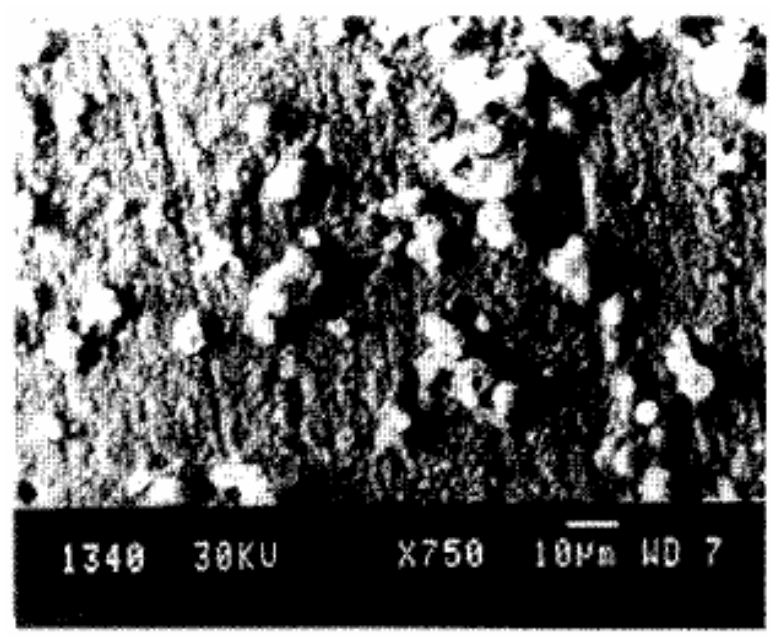

Figure 4a-II. SEM micrograph X750 showing partly covered surface by corrosion products in case of specimen immersed in $\mathrm{H}_{2} \mathrm{~S}$-saturated mogra water at $25^{\circ} \mathrm{C}$ for $2 \mathrm{~h}$.

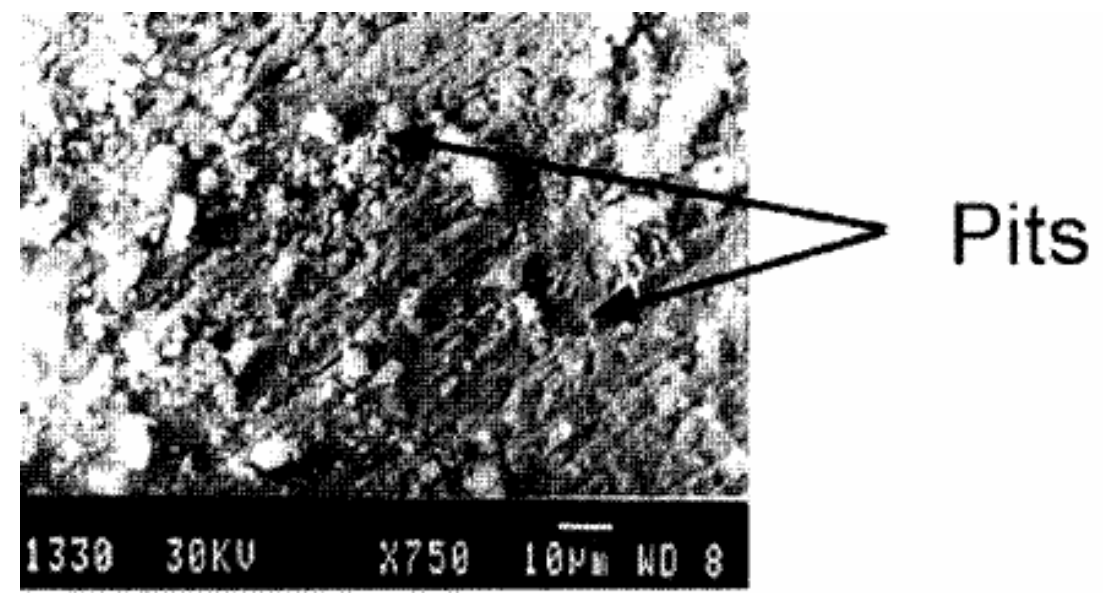

Figure 4a-III. SEM micrograph X750 showing partly covered surface by corrosion products and pits free of corrosion products in case of specimen immersed in $\mathrm{CO}_{2}-$ saturated mogra water at $25^{\circ} \mathrm{C}$ for $2 \mathrm{~h}$.

In the case of $\mathrm{CO}_{2}$-saturated mogra water the products cover only a small part of the area exposed to the solution. Cracks appear also in the corrosion products. This leads to lower corrosion resistance. The results obtained in Fig. 2 are supported by the micrographs in Fig. 4b. The higher corrosion resistance in the presence of $\mathrm{H}_{2} \mathrm{~S}$ as compared to $\mathrm{CO}_{2}$ can be accounted for by the insolubility of iron sulfides in $\mathrm{H}_{2} \mathrm{O}$ (both $\mathrm{FeS}$ and $\mathrm{FeS}_{2}$ ), whereas iron carbonate is sparingly soluble $\left(\mathrm{K}_{\mathrm{sp}}=3.13 \times 10^{-11}\right)$ [10]. 


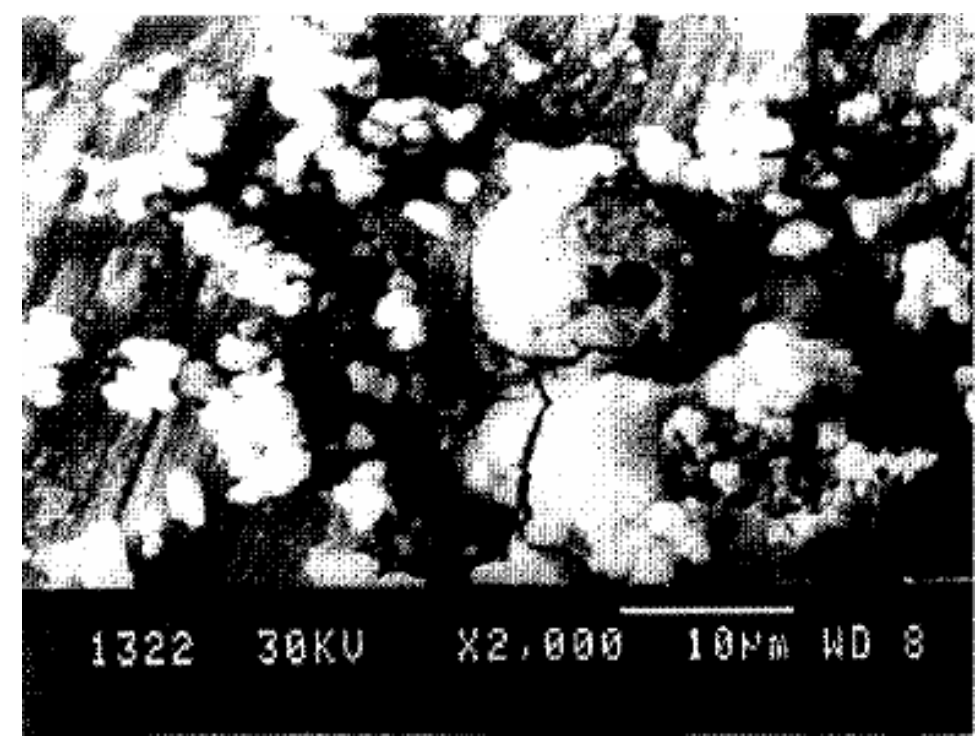

Figure 4b-I. SEM micrograph X2000 showing corrosion products precipitated in pits and also cracks appearance in the case of specimen immersed in mogra water at $25^{\circ} \mathrm{C}$ for $2 \mathrm{~h}$.

To further elucidate the effect of dissolved gases in mogra water, the electrode was polarized in mogra water saturated with either $\mathrm{CO}_{2}$ or $\mathrm{H}_{2} \mathrm{~S}$, Fig. 5. There is a shift of the corrosion potential to more negative values in the presence of both gases, which is more pronounced in the case of $\mathrm{H}_{2} \mathrm{~S}$. On anodic polarization in $\mathrm{H}_{2} \mathrm{~S}$ medium there is a small arrest in the potential current relation, which may be related to a more or less passive behavior of the electrode. As the potential becomes more positive, the current continues to increase indicating localized attack. At high polarization, either anodic or cathodic, the currents are high in the presence of dissolved $\mathrm{H}_{2} \mathrm{~S}$. This is more pronounced in the case of the cathodic current, which indicates that the protective FeS film formed under open-circuit conditions is more or less destroyed on polarization and that the film formed in the presence of $\mathrm{CO}_{2}$ is of a more resistive nature under polarization conditions. Both films are less protective than that formed in mogra water alone. 


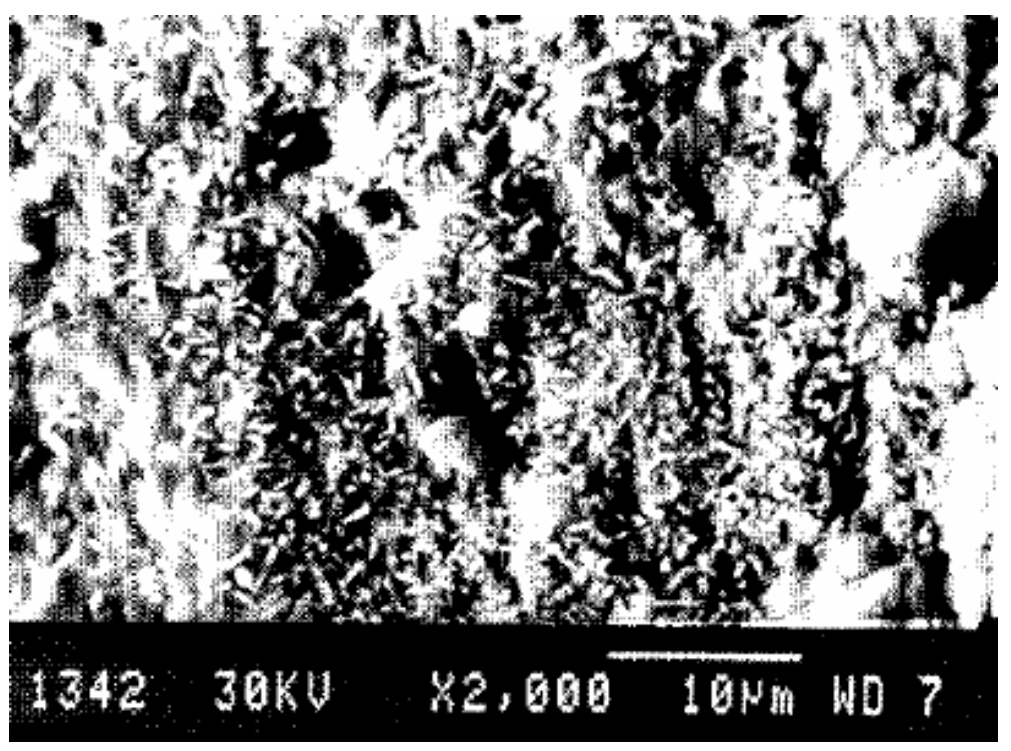

Figure 4b-II. SEM micrograph X2000 showing fine needle shaped deposits in the case of specimen immersed in $\mathrm{H}_{2} \mathrm{~S}$-saturated mogra water at $25^{\circ} \mathrm{C}$ for $2 \mathrm{~h}$, which are less protective than in the case of mogra water only.

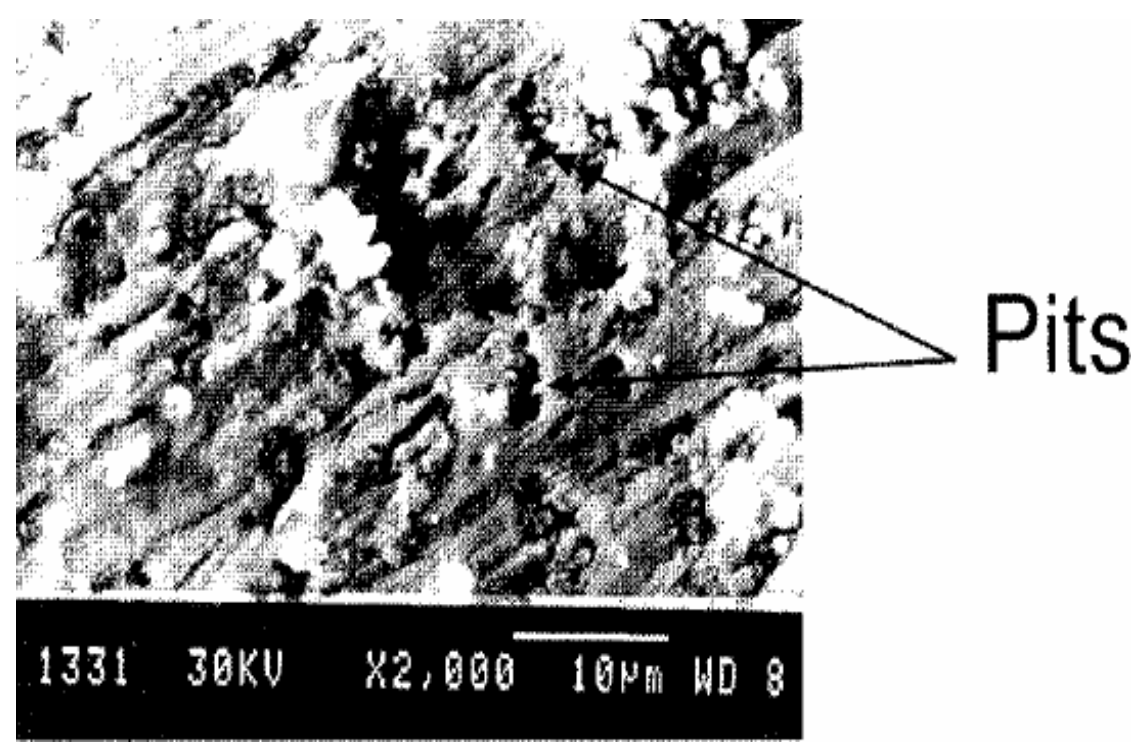

Figure 4b-III. SEM micrograph X2000 showing corrosion in the case of specimen immersed in $\mathrm{CO}_{2}$-saturated mogra water at $25^{\circ} \mathrm{C}$ for $2 \mathrm{~h}$. 


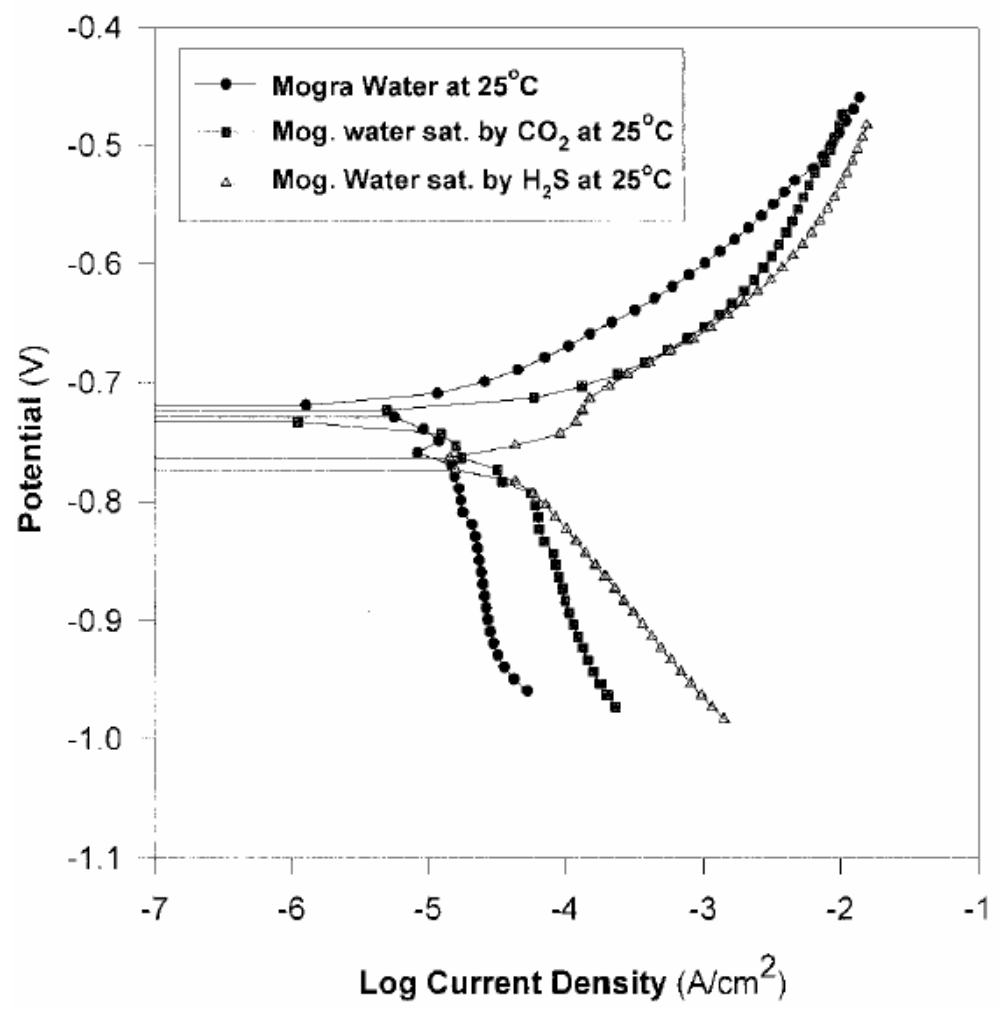

Figure 5. Effect of dissolved sour gases $\left(\mathrm{CO}_{2}\right.$ and $\left.\mathrm{H}_{2} \mathrm{~S}\right)$ in mogra water at $25^{\circ} \mathrm{C}$ on the Tafel-plot.

The effect of the presence of some foreign anions in a corrosive medium was also tested. A $0.5 \mathrm{M} \mathrm{H}_{2} \mathrm{SO}_{4}$ medium was chosen and some oxoanions were tested. The Nyquist plots after 2 hours immersion are shown in Fig. 6. It is evident that all the anions cause a decrease in the corrosion rate with different values as can be inferred from the increase in the diameter of the high frequency semicircle which determines the value of Rp (Table 2). An inductive loop appears in most cases, which is an indication of localized corrosion. In previous studies on the dissolution of aluminium and its alloys, the inductive loop has been attributed to the presence of adsorbed species that form during the dissolution of aluminium at the oxide/electrolyte interface, thus defining the Faradaic process $[11,12]$. 


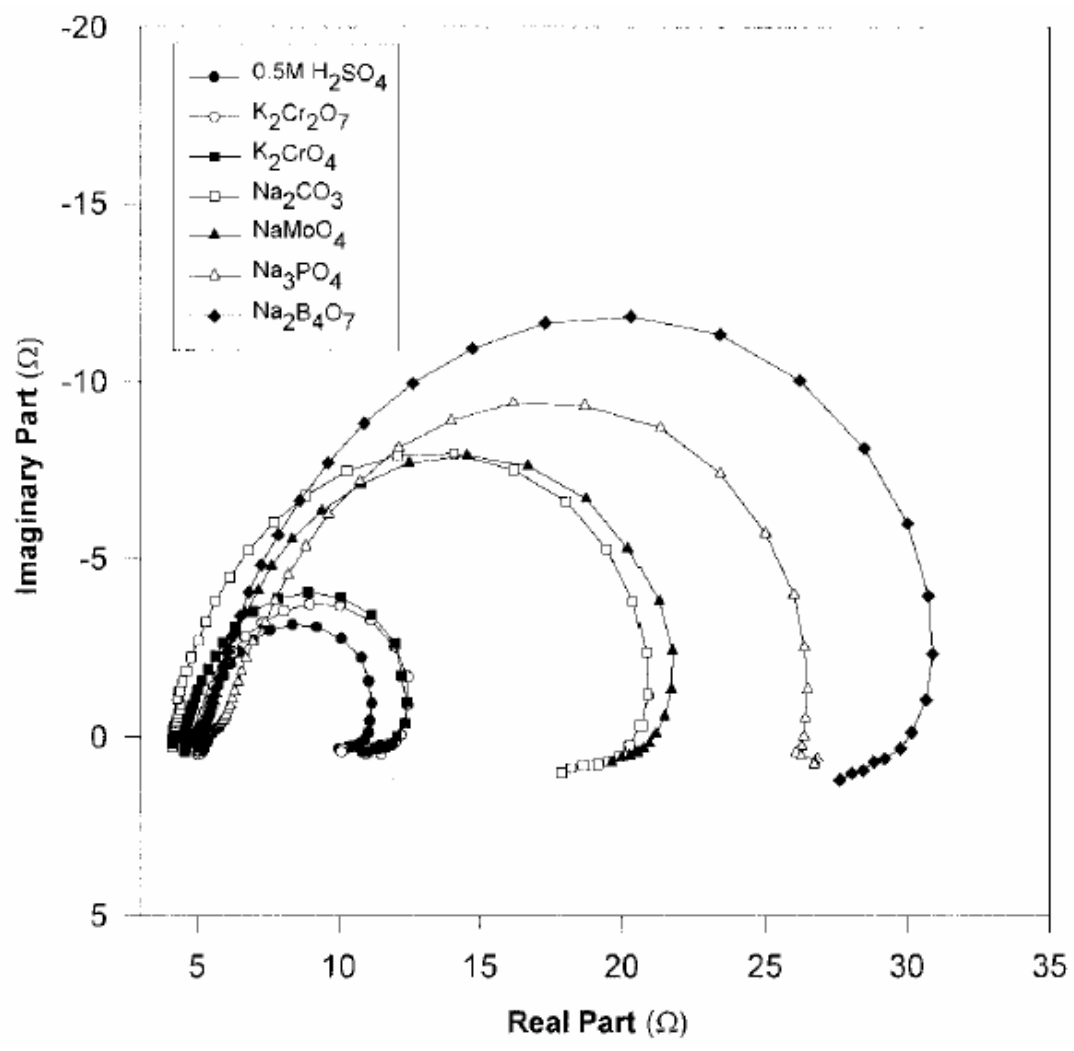

Figure 6. Nyquist-plot for $0.01 \mathrm{M}$ of different anions in $0.5 \mathrm{M} \mathrm{H}_{2} \mathrm{SO}_{4}$ at $25^{\circ} \mathrm{C}$.

The recorded Bode plots reflected the same trend. The highest impedance value recorded was for the electrode immersed in the presence of $\mathrm{Na}_{2} \mathrm{~B}_{4} \mathrm{O}_{7}$, while the lowest was that in the presence of $\mathrm{K}_{2} \mathrm{Cr}_{2} \mathrm{O}_{7}$, as shown in Table 2. In all cases the maximum phase shift $\theta_{\max }$ does not approach $90^{\circ}$, which is required for purely capacitive behavior. The present results can be compared with those reported in the literature by Rozenfield [13] for the protective concentration of different oxoanions for steel in $0.1 \mathrm{~N} \mathrm{Na}_{2} \mathrm{SO}_{4}$. These were $0.357,0.145,0.075,0.068$, 0.062, 0.060 and $0.026 \mathrm{~mol} \mathrm{~L}^{-1}$ for $\mathrm{NaHCO}_{3}, \mathrm{NaNO}_{2}, \mathrm{Na}_{2} \mathrm{CO}_{3}, \mathrm{~K}_{2} \mathrm{Cr}_{2} \mathrm{O}_{7}$, $\mathrm{Na}_{2} \mathrm{CrO}_{4}, \mathrm{Na}_{2} \mathrm{MoO}_{4}$ and $\mathrm{Na}_{3} \mathrm{PO}_{4}$, respectively. For the same sequence of anions the $\mathrm{Rp}$ values obtained in $0.5 \mathrm{M} \mathrm{H}_{2} \mathrm{SO}_{4}$ in the present study are $12.2,10.7,13.8$, $5.0,6.3,14.7$ and $21.4 \Omega$. With the exception of the first three media, the polarization resistance is best for the medium which requires the least concentration for protection from corrosion. The literature reports [10] that iron dichromate $\mathrm{Fe}_{2}\left(\mathrm{Cr}_{2} \mathrm{O}_{7}\right)_{3}$ is soluble in water and acids, whereas iron chromate $\mathrm{Fe}_{2}\left(\mathrm{CrO}_{4}\right)_{3}$ and iron phosphate are soluble in water. Therefore, it may be 
concluded that for $\mathrm{Cr}_{2} \mathrm{O}_{7}{ }^{2-}, \mathrm{CrO}_{4}{ }^{2-}, \mathrm{MoO}_{4}{ }^{2-}$ and $\mathrm{PO}_{4}{ }^{3-}$ media, the increase in $\mathrm{Rp}$ is due to the formation of increasingly insoluble corrosion products in $\mathrm{H}_{2} \mathrm{SO}_{4}$.

For $\mathrm{CO}_{3}{ }^{2-}, \mathrm{HCO}_{3}{ }^{-}$and $\mathrm{NO}_{2}^{-}$media, the somewhat high $\mathrm{Rp}$ values can be correlated with the formation of insoluble or slightly soluble corrosion products in $\mathrm{H}_{2} \mathrm{SO}_{4}$ medium.

Table 2. $\mathrm{Rp}$ values for $0.01 \mathrm{M}$ of different anions in $0.5 \mathrm{M} \mathrm{H}_{2} \mathrm{SO}_{4}$ at $25{ }^{\circ} \mathrm{C}$ after $2 \mathrm{~h}$ immersion.

\begin{tabular}{cc}
\hline Component & $\mathbf{R p}(\boldsymbol{\Omega})$ \\
\hline $\mathrm{Na}_{2} \mathrm{~B}_{4} \mathrm{O}_{7}$ & 22.6 \\
$\mathrm{Na}_{3} \mathrm{PO}_{4}$ & 21.4 \\
$\mathrm{NaMoO}_{4}$ & 14.7 \\
$\mathrm{Na}_{2} \mathrm{CO}_{3}$ & 13.8 \\
$\mathrm{NaHCO}_{3}$ & 12.2 \\
$\mathrm{NaNO}_{2}$ & 10.7 \\
$\mathrm{~K}_{2} \mathrm{CrO}_{4}$ & 6.3 \\
$\mathrm{~K}_{2} \mathrm{Cr}_{2} \mathrm{O}_{7}$ & 5.0 \\
\hline
\end{tabular}

A preliminary test showed that when $0.5 \mathrm{M} \mathrm{H}_{2} \mathrm{SO}_{4}$ electrolyte contained the same concentration of chloride ions $\left(10^{-2} \mathrm{M}\right)$, the $\mathrm{Rp}$ value recorded was $65.9 \Omega$, which is higher than that recorded in the presence of the oxoanions. Scanning electron micrographs of the specimen immersed in $0.5 \mathrm{M} \mathrm{H}_{2} \mathrm{SO}_{4}+10^{-2} \mathrm{M} \mathrm{Cl}^{-}$or $\mathrm{Cr}_{2} \mathrm{O}_{7}{ }^{2-}$ for $2 \mathrm{~h}$ are shown in Fig. 7. The morphology of the deposits differs, both at low and high magnifications. From the latter it is clear that the surface covered by corrosion products in the case of chloride medium is more than in dichromate medium. This results in better protection of the surface and therefore higher Rp value in chloride medium. There is competition between the aggressive nature of the chloride ion attacking the surface and its high adsorption power which leads to well adsorbed corrosion products. These cover the surface better than in the 
case of dichromate medium, as observed from Fig. 7, which results in the high Rp value obtained in chloride medium.

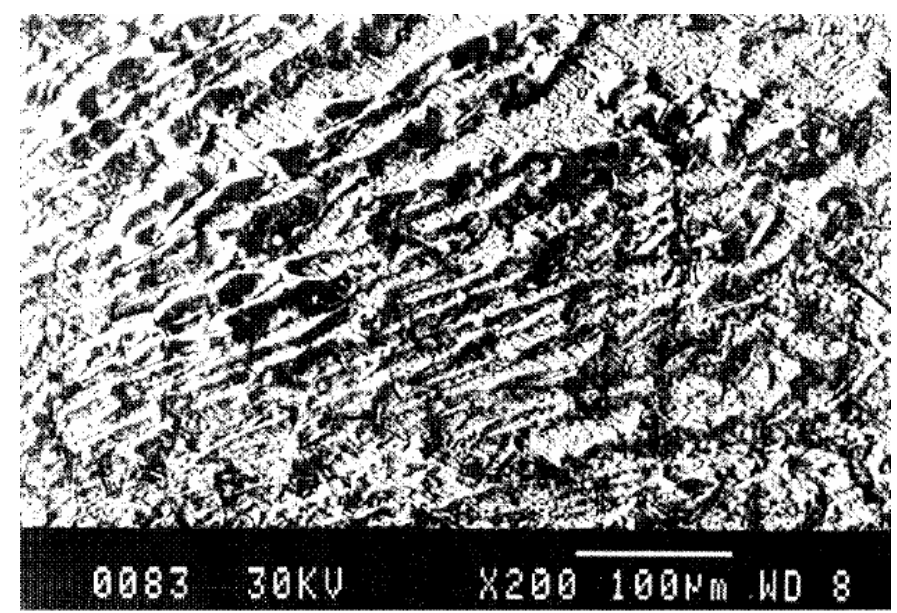

Figure 7a. SEM micrograph X200 showing the effect of $\mathrm{Cl}^{-}$ion on carbon steel in the case of specimen immersed in $0.01 \mathrm{M} \mathrm{Cl}^{-}$in $0.5 \mathrm{M} \mathrm{H}_{2} \mathrm{SO}_{4}$ at $25^{\circ} \mathrm{C}$ for $2 \mathrm{~h}$.

To compare the effect of halide ions, the impedance plots for $0.1 \mathrm{M} \mathrm{Cl}^{-}, \mathrm{Br}^{-}, \mathrm{I}^{-}$in $0.5 \mathrm{M} \mathrm{H}_{2} \mathrm{SO}_{4}$, are shown in Fig. 8. The action of anion-active substances to provide protection from corrosion follows the order $\mathrm{I}^{-}>\mathrm{Br}^{-}>\mathrm{Cl}^{-}$. This indicates that the surface is best protected in the presence of $\mathrm{I}^{-}$ions. The inductive loop, which indicates the presence of localized corrosion, is completely absent in the Nyquist plot.

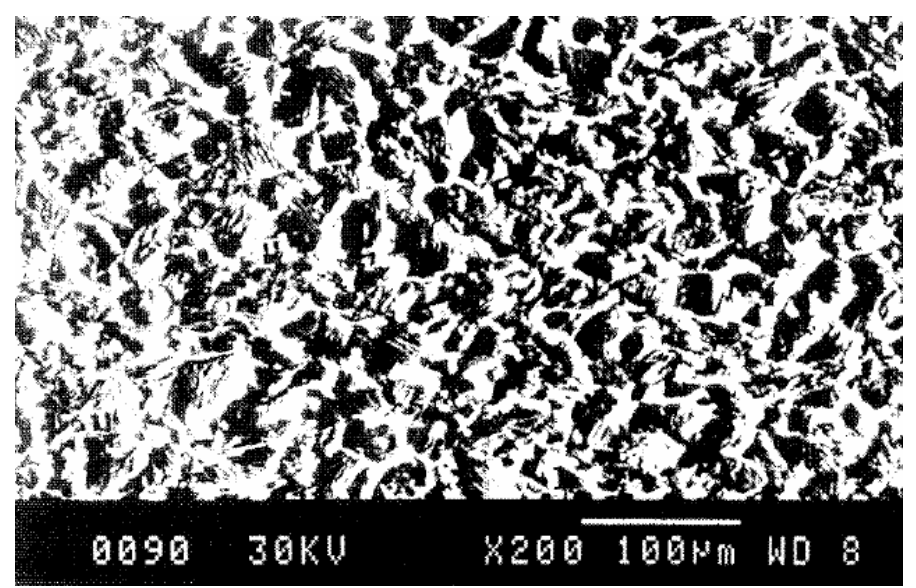

Figure 7b. SEM micrograph $\mathrm{X} 200$ showing the effect of $\mathrm{Cr}_{2} \mathrm{O}_{7}{ }^{2-}$ ion on carbon steel in the case of specimen immersed in $0.01 \mathrm{M} \mathrm{Cr}_{2} \mathrm{O}_{7}{ }^{2-}$ in $0.5 \mathrm{M} \mathrm{H}_{2} \mathrm{SO}_{4}$ at $25^{\circ} \mathrm{C}$ for $2 \mathrm{~h}$. 


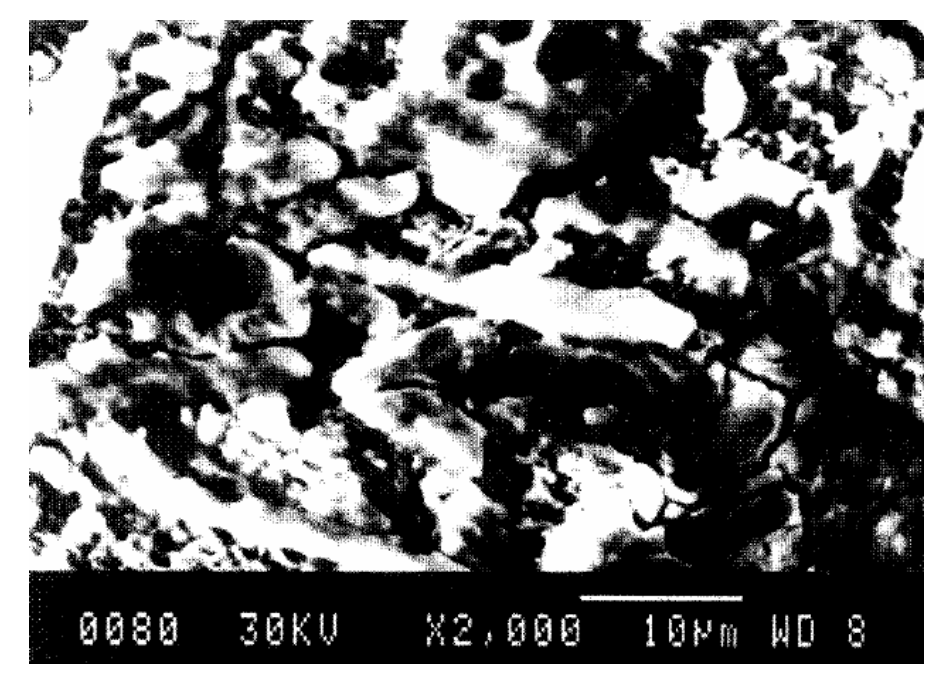

Figure 7c. SEM micrograph X2000 showing the effect of $\mathrm{Cl}^{-}$ion on carbon steel in the case of specimen immersed in $0.01 \mathrm{M} \mathrm{Cl}^{-}$in $0.5 \mathrm{M} \mathrm{H}_{2} \mathrm{SO}_{4}$ at $25^{\circ} \mathrm{C}$ for $2 \mathrm{~h}$.

Table 3 gives the value of Rp and $\theta_{\max }$ after 30 and 120 minutes immersion in 0.5 $\mathrm{M} \mathrm{H}_{2} \mathrm{SO}_{4}$ containing $\mathrm{I}^{-}, \mathrm{Br}^{-}$or $\mathrm{Cl}^{-}$ions. In the case of $\mathrm{Br}^{-}$and $\mathrm{I}^{-}$there is increasing of both $\mathrm{Rp}$ and $\theta_{\max }$ with time indicating increasing in corrosion protection with time. The value of Rp somewhat decreased with time in the case of $\mathrm{Cl}^{-}$, due to the competition between its aggressive nature and the adsorption of the corrosion products. The results show that the surface is best protected in the case of $\mathrm{I}^{-}$, due to its superior adsorption ability.

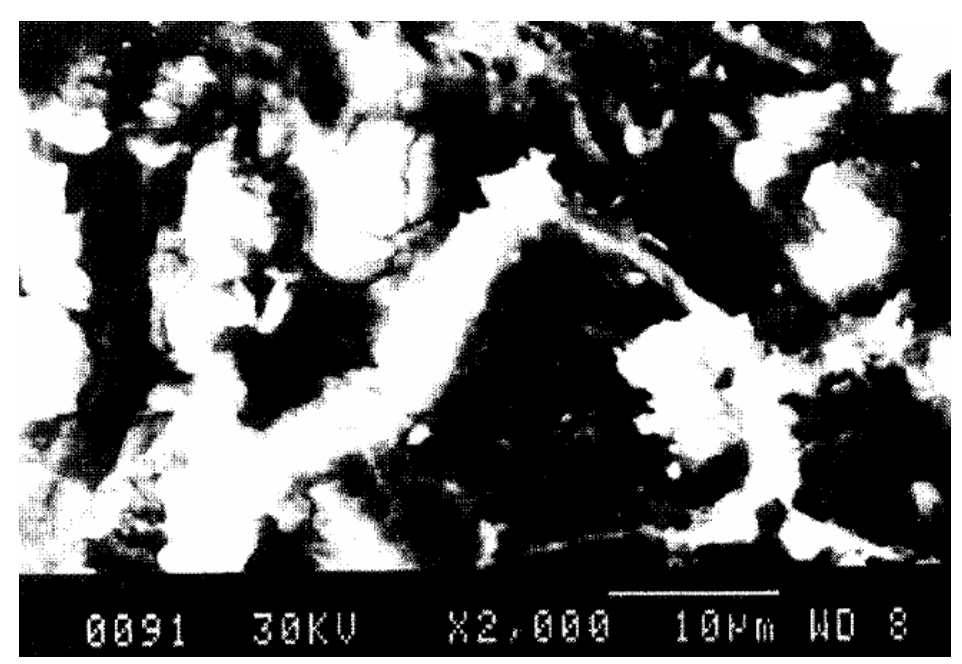

Figure 7d. SEM micrograph X2000 showing the effect of $\mathrm{Cr}_{2} \mathrm{O}_{7}{ }^{2-}$ ion on carbon steel in the case of specimen immersed in $0.01 \mathrm{M} \mathrm{Cr}_{2} \mathrm{O}_{7}{ }^{2-}$ in $0.5 \mathrm{M} \mathrm{H}_{2} \mathrm{SO}_{4}$ at $25^{\circ} \mathrm{C}$ for $2 \mathrm{~h}$. 
It is observed that the order of increase in $\mathrm{Rp}$ follows the rate of specific adsorption of the halide ions; therefore it should be assumed that the decrease in the corrosion rate is correlated with the adsorption of these ions and/or the corrosion products on the electrode surface.

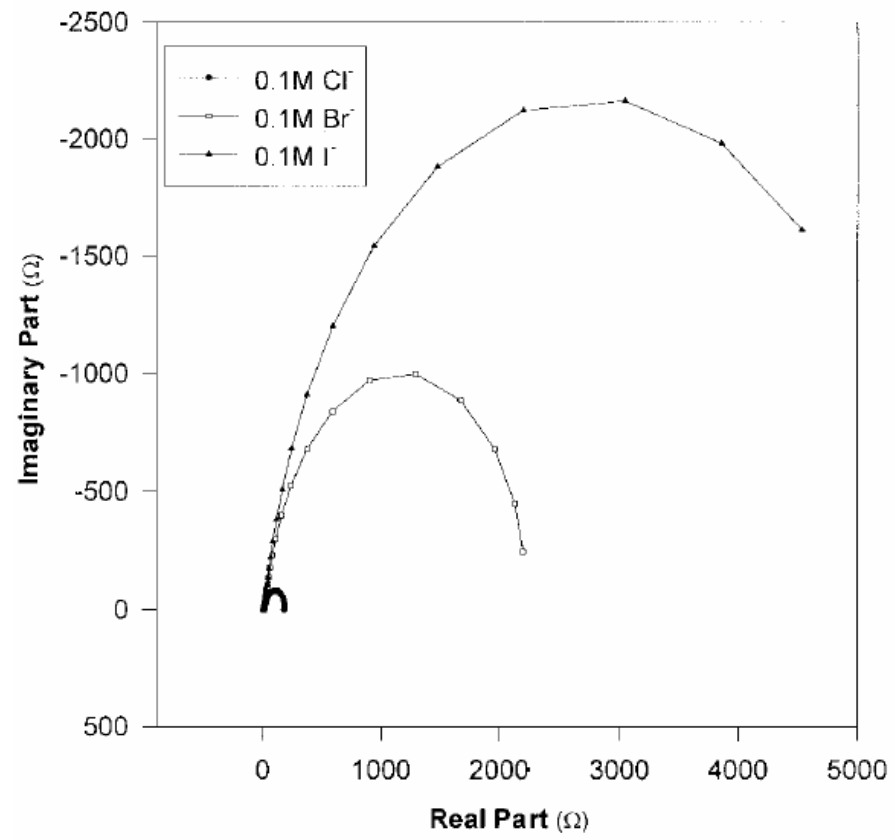

Figure 8. Nyquist-plot for $0.1 \mathrm{M}$ of different halides in $0.5 \mathrm{M} \mathrm{H}_{2} \mathrm{SO}_{4}$ at $25^{\circ} \mathrm{C}$.

Table 3. Rp and $\theta_{\max }$ values for $0.1 \mathrm{M}$ of different halides in $0.5 \mathrm{M} \mathrm{H}_{2} \mathrm{SO}_{4}$ at $25{ }^{\circ} \mathrm{C}$ after 30 and $120 \mathrm{~min}$.

\begin{tabular}{|c|c|c|c|c|}
\hline \multirow{2}{*}{$0.1 \mathrm{M}$ halide ion } & \multicolumn{2}{|c|}{$\mathrm{Rp}(\Omega)$} & \multicolumn{2}{c|}{$\theta_{\max }{ }^{\mathrm{O}}$} \\
\cline { 2 - 5 } & $30 \mathrm{~min}$ & $120 \mathrm{~min}$ & $30 \mathrm{~min}$ & $120 \mathrm{~min}$ \\
\hline $\mathrm{Cl}^{-}$ & 216 & 176 & 51.5 & 58.9 \\
\hline $\mathrm{Br}^{-}$ & 1410 & 2200 & 66.7 & 71.5 \\
\hline $\mathrm{I}^{-}$ & 3530 & 4800 & 72.2 & 74.2 \\
\hline
\end{tabular}

A small hump appears on the central downward sloping portion of the Bode plot in the presence of $\mathrm{I}^{-}$and $\mathrm{Br}^{-}$ions. This irregularity was attributed before to the pore resistance due to electrolyte penetration [14]. 


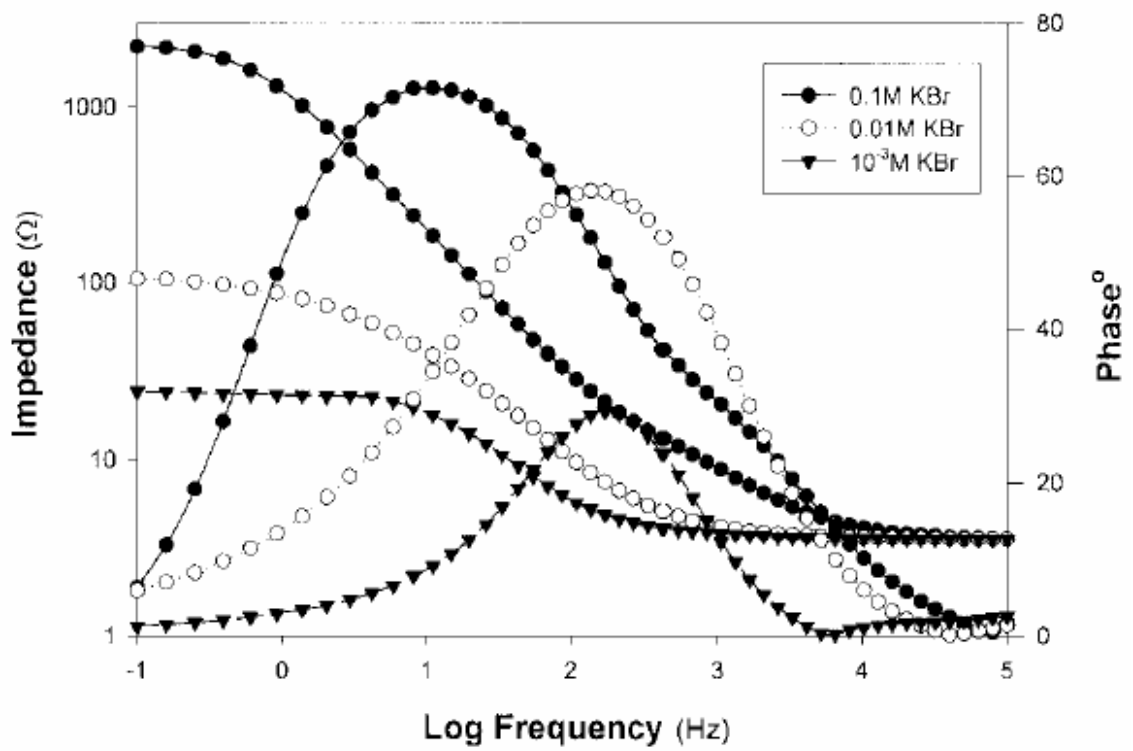

Figure 9a. Bode-plot for different concentrations of $\mathrm{Br}^{-}$in $0.5 \mathrm{M} \mathrm{H}_{2} \mathrm{SO}_{4}$ at $25{ }^{\circ} \mathrm{C}$ after $2 \mathrm{~h}$ immersion.

The effect of concentration of $\mathrm{Br}^{-}$and $\mathrm{Cl}^{-}$ions on the open circuit impedance plots was tested. In Fig. 9, the Bode plot shows a regular increase in the impedance with an increase in halide concentration, indicating an increase in the polarization resistance. An accompanying increase in the diameter of the semicircle in the Nyquist plot was observed. The estimated values of polarization resistance, $R p$ and $\theta_{\max }$ as a function of halide ion concentration and time are given in Table 4. The value of $\mathrm{Rp}$ increases with increasing halide ion concentration, which indicates the prevalence of adsorption over attack by the ion. On the other hand, Rp was found to decrease with time, except at the highest $\mathrm{Br}^{-}$concentration, which indicates that adsorption of corrosion products hinders dissolution of the specimen. The value of $\mathrm{Rp}$ also decreases with time in the blank solution, due to the attack of the specimen by the medium. 


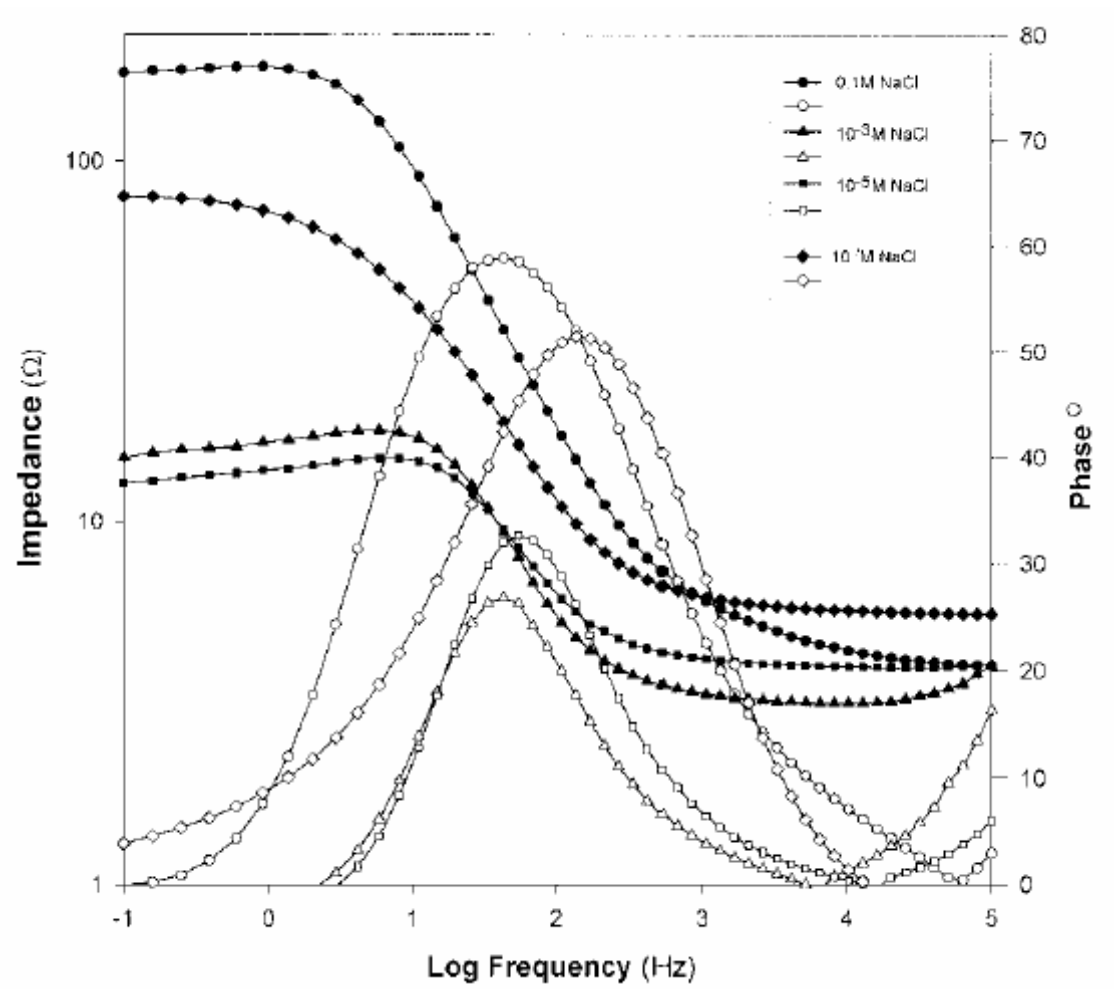

Figure 9b. Bode-plot for different concentrations of $\mathrm{Cl}^{-}$in $0.5 \mathrm{M} \mathrm{H}_{2} \mathrm{SO}_{4}$ at $25{ }^{\circ} \mathrm{C}$ after $2 \mathrm{~h}$ immersion.

The results can be explained by formation of a small quantity of corrosion products on the surface leaving an area exposed for further attack when the halide ion concentration is low. At higher concentrations, the surface is more or less completely covered by corrosion products and therefore Rp increases. An evidence of the prevalence of adsorption over attack is that the rate of increase in Rp with concentration is greater in the presence of $\mathrm{Br}^{-}$than $\mathrm{Cl}^{-}$ions, since the former ion is known to be more specifically adsorbed than $\mathrm{Cl}^{-}$. Also, at the highest $\mathrm{Br}^{-}$concentration $\mathrm{Rp}$ was found to increase with time.

In general $\theta_{\max }$ increases and shifts to lower frequency ranges with increase in halide ion concentration. This increase in $\theta_{\max }$ is attributed to the capacitive behavior of the system as a result of the sealing of the electrode surface by corrosion products, thus leading to higher resistance to corrosion. 


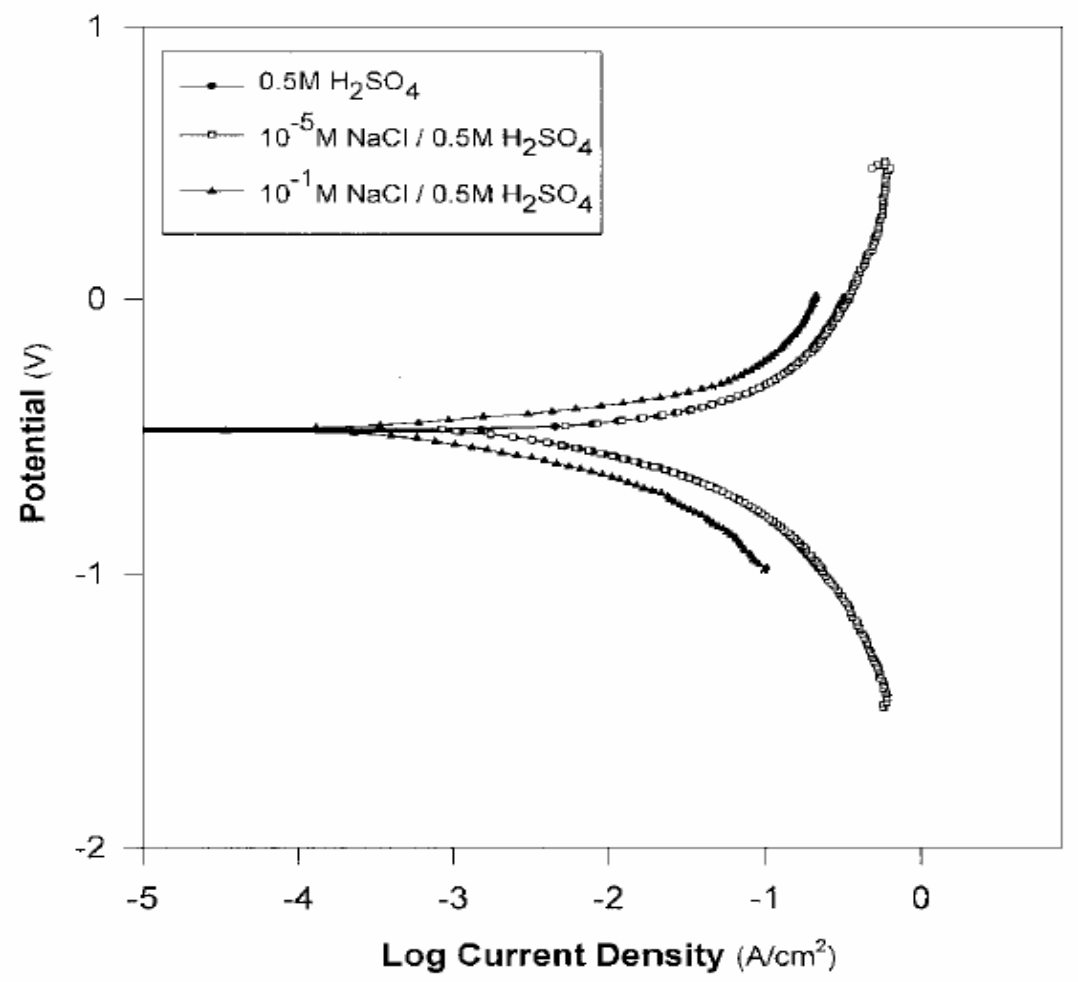

Figure 10. Tafel-plot for different concentrations of $\mathrm{Cl}^{-}$in $0.5 \mathrm{M} \mathrm{H}_{2} \mathrm{SO}_{4}$ at $25^{\circ} \mathrm{C}$.

Table 4. Rp and $\theta_{\max }$ values for different concentrations and time of different halides in $0.5 \mathrm{M} \mathrm{H}_{2} \mathrm{SO}_{4}$ at $25{ }^{\circ} \mathrm{C}$ after 30 and 120 min immersion.

\begin{tabular}{|c|c|c|c|c|c|}
\hline \multirow{2}{*}{ Halide ion concentration } & \multicolumn{2}{|c|}{$\operatorname{Rp}(\Omega)$} & \multicolumn{2}{c|}{$\theta_{\max }{ }^{\circ}$} \\
\cline { 2 - 6 } & $30 \mathrm{~min}$ & $120 \mathrm{~min}$ & $30 \mathrm{~min}$ & $120 \mathrm{~min}$ \\
\hline \multicolumn{2}{|c|}{ Blank $\left(0.5 \mathrm{M} \mathrm{H}_{2} \mathrm{SO}_{4}\right)$} & 14.6 & 4.7 & 35.7 & 14.1 \\
\hline \multirow{3}{*}{$\mathrm{Cl}^{-}$} & $10^{-3} \mathrm{M}$ & 31.6 & 11.0 & 29.1 & 26.5 \\
\cline { 2 - 6 } & $0.01 \mathrm{M}$ & 87.7 & 65.9 & 50.6 & 51.4 \\
\cline { 2 - 6 } & $0.1 \mathrm{M}$ & 217 & 176 & 51.5 & 58.9 \\
\hline \multirow{3}{*}{$\mathrm{Br}^{-}$} & $10^{-3} \mathrm{M}$ & 57.8 & 19.0 & 50.8 & 29.3 \\
\cline { 2 - 6 } & $0.01 \mathrm{M}$ & 172 & 99.8 & 57.0 & 58.1 \\
\cline { 2 - 6 } & $0.1 \mathrm{M}$ & 1410 & 2200 & 66.7 & 71.5 \\
\hline
\end{tabular}

The effect of concentration of chloride ion on the polarization behavior of C-steel is shown in Fig. 10. The corrosion current decreased systematically from 1.37 $\mathrm{mA}$ for $10^{-5} \mathrm{M} \mathrm{Cl}^{-}$to $165 \mu \mathrm{A}$ for $10^{-1} \mathrm{M} \mathrm{Cl}^{-}$. The polarization experiments 
indicate that the behavior of the electrode is the same as when it is under open circuit conditions. Increase in $\mathrm{Rp}$, as the $\mathrm{Cl}^{-}$ion concentration increased, observed in impedance experiments, as well as the decrease observed in the corrosion current under polarization conditions, are due to the increase in passivation condition of the $\mathrm{C}$-steel as a result of surface coverage by the corrosion products.

\section{Conclusions}

1. The surface is protected in the presence of mogra water only by corrosion products. In case of $\mathrm{H}_{2} \mathrm{~S}$-saturated mogra water the needle shaped deposits offer less protection and few pits are observed. The attack is highest in $\mathrm{CO}_{2}$-saturated mogra water, where corrosion products are less and appear to be cracked.

2. The Rp values were observed to be higher in the presence of halide ions than oxoanions, which appears to be correlated with the formation of dense corrosion products which cover the surface in case of halide ions better than oxoanions.

3. The behavior of the specimen in the presence of halide ions is sensitive to both concentration and time of immersion. Increase in concentrations increases Rp, whereas increase in time decreases Rp. The increase of Rp with concentration is due to sealing of the electrode surface by corrosion products, which prevents further attack. The corrosion protection follows the order $\mathrm{I}^{-}>\mathrm{Br}^{-}>\mathrm{Cl}^{-}$.

\section{References}

1. C. De Waard, D.E. Millians, Corrosion 31 (1975) 177.

2. K.Videm, A. Dugstad, paper 42, presented at Corrosion '87, NACE, Houston, TX (1987).

3. G-Schmitt, paper 43, presented at Corrosion '83, NACE, Houston, TX (1983).

4. K. Viden, A. Dugstad, paper 186, presented at Corrosion '88, NACE, Houston, TX (1988). 
5. S.A. Salih, A.G. Gas-Allah, A.A. Mazhar, R.H. Tammam, J. Appl. Electrochem. 31 (2001) 1103.

6. M. Metikos-Hukovic, R. Babic, Z. Grubac, S. Brinic, J. Appl. Electrochem. 24 (1994) 772.

7. $\quad$ F. Mansfeld, J. Appl. Electrochem. 25 (1995) 187.

8. G.I. Ogundele, W.E. White, Corrosion 42 (1986) 71.

9. Z. Quan, S. Chen, X. Cui, Y. Zi, Corrosion 58 (3) (2002) 248.

10. Handbook of Chemistry and Physics. David R. Lide, $2^{\text {nd }}$ Edn. 2001-2002, CRC Press, Florida.

11. S. Gudic, J. Radosevic, M. Kliskic, J. Appl. Electrochem. 26 (1996) 1027.

12. W.N. Garrad, Corros. Sci. 50 (1994) 215.

13. I.L. Rozenfield, Corrosion Inhibitors, McGraw - Hill, New York, 1981.

14. G.W. Water, Corros. Sci. 26(8) (1986) 681. 